\title{
Efektivitas model pembelajaran ARCS terhadap kemampuan menulis surat pribadi siswa kelas VII SMPN II Medan
}

\section{Ervira Dwi Lesmana ${ }^{\mathrm{I}}$, Fitriani Lubis ${ }^{2}$}

Bahasa dan Sastra Indonesia, Bahasa dan Seni, Universitas Negeri Medan, J1. Rumah Sakit H., Kenangan Baru, Kecamatan Percut Sei Tuan, Medan, Indonesia

I'erviralesmana@gmail.com ; ${ }^{2}$ rianiayandi@gmail.com

* Corresponding author: erviralesmana@gmail.com

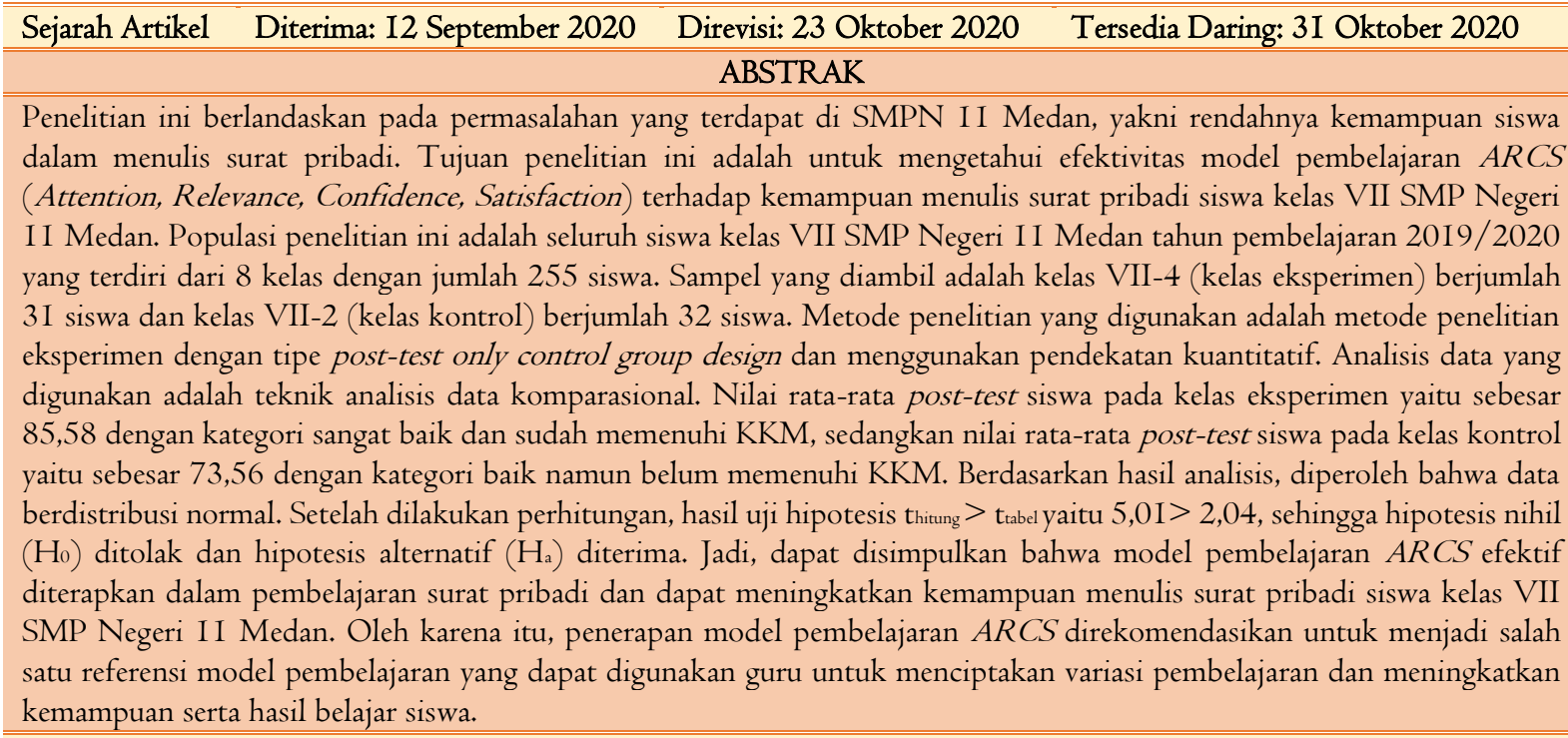

\section{Kata Kunci $\quad$ Model $A R C S$, Model konvensional, Surat pribadi} ABSTRACT

This research is based on the problems found in SMPN II Medan, namely the low ability of students to write personal letters. The purpose of this study was to determine the effectiveness of the ARCS (Attention, Relevance, Confidence, Satisfaction) learning model on the ability to write personal letters of seventh-grade students of SMP Negeri II Medan. This study's population were all grade VII students of SMP Negeri II Medan in the 20I9/2020 learning year, which consisted of 8 classes with a total of 255 students. The samples taken were class VII-4 (experimental class), totaling 3 I students and class VII-2 (control class), totaling 32 students. The research method used is an experimental research method with the type of post-test only control group design and uses a quantitative approach. The data analysis used was the comparational data analysis technique. The average post-test score of students in the experimental class was 85.58 in the very good category and had fulfilled the KKM, while the post-test average score of students in the control class was 73.56 in the good category but did not fulfill the KKM. Based on the results of the analysis, it was found that the data were normally distributed. After calculating, the results of the hypothesis test $t_{\text {count }}>$ table are 5.0I $>2.04$, so the null hypothesis (HO) is rejected and the alternative hypothesis $(\mathrm{Ha})$ is accepted. So, it can be concluded that the ARCS learning model is effectively applied in private letter learning and can improve the personal letter writing skills of seventh grade students of SMP Negeri II Medan. Therefore, the ARCS learning model's application is recommended to be a reference for learning models that teachers can use to create learning variations and improve student learning abilities and outcomes.

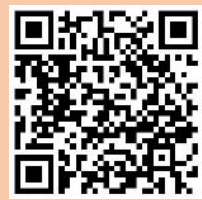

Copyright@2020, Ervira Dwi Lesmana, Fitriani Lubis This is an open access article under the CC-BY-3.0 license

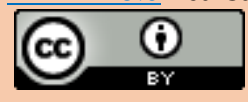

\section{Keywords ARCS model, Conventional model, Private letter}

How to Cite Lesmana, E. D., \& Lubis, F. (2020). Efektivitas model pembelajaran ARCS terhadap kemampuan menulis surat pribadi siswa kelas VII SMPN II Medan. KEMBARA: Jurnal Keilmuan Bahasa, Sastra, dan Pengajarannya (e-Journal), 6(2). I70-I87. doi: https://doi.org/I0.22219/kembara.v6i2.13989 


\section{PENDAHULUAN}

Kurikulum merupakan elemen yang sangat penting dalam pendidikan. Berdasarkan UU No. 20 Tahun 2003 tentang Sistem Pendidikan Nasional yang memaparkan bahwa pengertian kurikulum adalah seperangkat rencana dan pengaturan mengenai tujuan, isi, dan bahan pelajaran serta cara yang digunakan sebagai pedoman penyelenggara kegiatan pembelajaran untuk mencapai tujuan pendidikan tertentu. Sejak tahun 2013 pendidikan di Indonesia telah menerapkan kurikulum 2013. Tujuan kurikulum 2013 mencakup empat kompetensi, yaitu (I) kompetensi sikap spiritual, (2) sikap sosial, (3) pengetahuan, dan (4) keterampilan. Dalam mata pelajaran bahasa Indonesia, menulis merupakan salah satu aspek keterampilan. Menulis juga merupakan hal yang harus dicapai dalam mempelajari bahasa. Sebab pada dasarnya, tujuan pembelajaran bahasa adalah membimbing perkembangan bahasa siswa secara berkelanjutan melalui proses membaca, menulis, menyimak dan berbicara (Atmazaki, 2013).

Menulis merupakan kegiatan menyampaikan pesan (berkomunikasi) dalam bentuk tertulis kepada pihak lain dengan menggunakan bahasa tulis sebagai alat ataupun medianya (Dalman, 2013: 3). Menulis membutuhkan proses berpikir untuk menyampaikan gagasan atau pesan (informasi). Sesuai dengan pernyataan Saddhono dan Slamet (20I4) bahwa menulis merupakan kegiatan yang sangat kompleks karena melibatkan cara berpikir yang teratur dan berbagai persyaratan yang berkaitan dengan teknik penulisan, antara lain: (I) adanya kesatuan gagasan, (2) penggunaan kalimat yang jelas, (3) paragraf disusun dengan baik, (4) penerapan kaidah ejaan yang benar, serta (5) penggunaan kosakata.

Menulis surat pribadi merupakan salah satu kompetensi yang harus dikuasai oleh siswa kelas VII SMP/MTs dalam pembelajaran bahasa Indonesia. Hal tersebut telah ditetapkan dalam Kompetensi Dasar (KD) 4.I2, yaitu menulis surat (pribadi dan dinas) dengan memperhatikan struktur teks, kebahasaan dan isi. Berdasarkan KD tersebut, siswa kelas VII dituntut untuk mampu dan diharapkan untuk terampil dalam menulis surat pribadi. Surat pribadi bukan merupakan suatu bentuk tulisan yang terbilang rumit. Sebab pada dasarnya surat pribadi menurut Dewi (20I4) adalah alat komunikasi yang digunakan sebagai sarana menyampaikan suatu berita atau informasi kepada siapapun dengan menggunakan bahasa tulisan. Pada dasarnya, menulis surat pribadi dapat melatih cara berpikir siswa dengan menyesuaikan penggunaan bahasa surat dengan penerima surat. Selain itu, surat pribadi merupakan salah satu bentuk tulisan yang terbilang cukup sederhana dan tidak begitu rumit. Meskipun demikian, realita yang terjadi adalah tidak semua siswa SMP Negeri I I Medan dapat menulis surat pribadi dengan baik.

Berdasarkan observasi dan peninjauan lapangan pada tahun 2019, hasil yang diperoleh adalah dari 32 siswa hanya 68,75\% siswa yang sudah mencapai Kriteria Ketuntasan Minimum (KKM) dan 3I,25\% siswa belum mencapai kriteria ketuntasan minimum (KKM). Oleh sebab itu, kemampuan siswa dalam menulis surat pribadi masih terbilang cukup rendah. Hal ini dikarenakan siswa mengalami kesulitan-kesulitan saat menulis surat pribadi, antara lain: (I) siswa sulit menuangkan gagasan ke dalam bentuk tulisan, (2) siswa sulit untuk menyesuaikan penulisan dengan bagian-bagian (sistematika) surat pribadi yang telah ditetapkan, (3) menggunakan diksi dengan tepat, serta (4) menuliskan ejaan dan menggunakan tanda baca dengan benar. Kesulitan yang dialami siswa memiliki kesamaan dengan penelitian yang dilakukan oleh Sriyanti (2017) bahwa siswa kelas VII MTs Negeri I5 Ciamis juga mengalami kesulitan dalam menulis surat pribadi. Kesulitan-kesulitan tersebut diantaranya: (I) siswa masih banyak yang belum memahami bagian-bagian surat pribadi, (2) siswa juga belum dapat membedakan komposisi surat pribadi dengan bahasa yang komunikatif.

Selanjutnya peneliti juga melakukan wawancara kepada salah seorang guru bahasa Indonesia di SMP Negeri II Medan. Kenyataan lain yang didapatkan adalah model pembelajaran yang digunakan guru terbilang kurang bervariasi dan cenderung monoton. Maka, perlu dilakukan model pembelajaran yang variatif yang dapat dijadikan sebagai pedoman pembelajaran untuk mencapai tujuan pembelajaran.

Model pembelajaran yang biasa diterapkan oleh guru dalam pembelajaran menulis surat pribadi merupakan model pembelajaran konvensional. Hal tersebut membuat siswa tidak termotivasi dalam belajar ataupun menulis. Motivasi dan belajar merupakan dua hal yang saling mempengaruhi. Motivasi belajar dapat timbul karena faktor intrinsik berupa keinginan berhasil dan dorongan kebutuhan belajar

Ervira Dwi Lesmana, Fitriani Lubis, Efektivitas model pembelajaran ARCS terhadap kemampuan menulis surat pribadi siswa kelas VII SMPN 11 Medan 
dan harapan akan cita-cita. Faktor ekstrinsiknya adalah adanya penghargaan, kegiatan belajar yang menarik dan lingkungan belajar yang kondusif (Uno 20I I).

Motivasi memiliki dua peranan penting dalam belajar. Pertama, motivasi membantu siswa dalam mencapai tujuan (Siregar dan Nara, 2016) sebab motivasi merupakan daya penggerak psikis dalam diri siswa. Kedua, motivasi memiliki peranan penting dalam memberikan rasa semangat, gairah serta rasa senang dalam melangsungkan pembelajaran, sehingga dalam melangsungkan kegiatan belajar mengajar, siswa memiliki energi yang banyak sebab memiliki motivasi yang tinggi. Selain itu, seorang siswa yang mempunyai motivasi yang tinggi dalam belajar memungkinkan siswa tersebut memperoleh hasil belajar yang tinggi pula. Ini berarti bahwa semakin tinggi motivasi dan upaya yang dilakukan, maka semakin tinggi hasil belajar yang akan diperoleh (Hamdu and Agustina, 20II).

Sehubungan dengan kemampuan menulis surat pribadi, (Sriyanti, 2017; Suyatna, 2017; Fajriyah dan Wagiran, 20I8) telah melakukan penelitian yang dilakukan dengan cara menerapkan model-model pembelajaran untuk meningkatkan kemampuan siswa dalam menulis surat pribadi. Oleh sebab itu, dalam penelitian ini dibutuhkan adanya penerapan perlakuan untuk mengatasi kesulitan-kesulitan yang dialami siswa dalam menulis dan meningkatkan kemampuan siswa menulis surat pribadi. Hambatan utama siswa adalah siswa merasa tidak termotivasi untuk belajar dan menulis sehingga mengalami berbagai kesulitan tersebut. Maka, salah satu model pembelajaran yang tepat untuk menerapkan pembelajaran menulis surat pribadi dan meningkatkan motivasi siswa adalah model pembelajaran $A R C S$. Model pembelajaran $A R C S$ adalah model pembelajaran yang terdiri dari empat komponen, yakni: Attention (perhatian), Relevance (relevansi), Confidence (percaya diri) dan Satisfaction (kepuasan) yang merupakan suatu bentuk pemecahan masalah dalam merancang motivasi siswa terutama untuk memperoleh pengetahuan yang baru (Keller, 2010). Model pembelajaran ARCS ini dapat meningkatkan motivasi siswa dengan tujuan mampu meningkatkan hasil belajar siswa (Degeng dalam Wena, 20II). Terdapat beberapa kelebihan yang dimiliki oleh model ARCS (Anowiyi dalam Aryawan, Lasmawan, dkk, 20I4), yakni: (I) model yang berlandaskan motivasi dan diperkuat dengan rancangan bentuk pembelajaran yang berpusat pada siswa, (2) memberikan petunjuk dan memberi arahan secara rinci tentang apa yang harus dilakukan oleh siswa, (3) penerapan model $A R C S$ dapat meningkatkan motivasi siswa untuk mengulang materi pembelajaran yang hakikatnya kurang menarik, (4) memiliki penilaian yang menyeluruh terhadap kemampuan yang lebih dari karakteristik-karakteristik siswa agar pembelajaran lebih efektif.

Berbagai penelitian yang mengaji tentang model pembelajaran ARCS ini telah dilakukan baik di dalam maupun di luar negeri. Beberapa penelitian di Indonesia (Setyadin \& Joko, 2013; Nirbita, 2017; Khori, 2018; Stefany, Candiasa, \& Warpala, (2016); Nugroho dan Wahyuni, 2018; Aryawan dkk., 20I4) telah mengaji model pembelajaran $A R C S$ terhadap peningkatan hasil belajar dan motivasi siswa (Santiani, 2013) serta peningkatan kemampuan berbicara (Munawarah, dkk, 2018). Beberapa penelitian yang mengaji model pembelajaran $A R C S$ di berbagai negara, seperti di Malaysia (Wah, 2015) dan (Annamalai, 2016) menggunakan model ARCS untuk membuat bahan ajar (e-book), Thailand (Popovich, 2000), Cina (W. Zhang, 2017 dan J. Zhang, 20I5), India (Malik, 20I4), Iran (Molaee \& Dortaj, 2015) dan Amerika Serikat (Li dan Keller, 2018; Keller, 2017).

Sejalan dengan informasi tersebut, penelitian yang meneliti tentang model pembelajaran ARCS terhadap kemampuan menulis surat pribadi belum pernah dilakukan. Penelitian seperti ini cukup penting dilakukan untuk menambah informasi dan wawasan guru tentang penerapan model baru dalam pembelajaran. Peneliti akan menerapkan model $A R C S$ pada pembelajaran menulis surat pribadi untuk mengatasi kesulitan siswa dalam menulis surat pribadi dengan menggunakan media yang diharapkan dapat mendukung keberhasilan penerapan model ini. Karena pada hakikatnya, tujuan pemanfaatan media adalah untuk meningkatkan efektivitas dan efisiensi pengajaran (Umar, 20I4).

Media yang digunakan adalah media audio. Model ARCS memiliki pengaruh yang signifikan dalam menyimak cerita rakyat (Rahayu, 2015). Menyimak memiliki kaitan erat dengan media audio. Dengan berhasilnya model $A R C S$ saat diterapkan dalam pembelajaran menyimak serta dengan adanya media audio yang digunakan dalam penelitian ini, maka keduanya dapat dikolaborasikan. Keduanya 
diharapkan dapat memaksimalkan penerapan model $A R C S$ serta dapat menunjang keberhasilan penelitian ini.

Media audio yang digunakan dalam penerapan model ini digunakan untuk memperkuat dua komponen model ARCS, yaitu: komponen perhatian (attention) dan relevansi (relevance). Media ini dibuat secara mandiri oleh peneliti untuk mendukung keberhasilan penerapan model ARCS dalam meningkatkan kemampuan siswa menulis surat pribadi. Oleh sebab itu, sebagai tolok ukur keefektifan penerapan model pembelajaran $A R C S$ dalam pembelajaran menulis surat pribadi, maka peneliti akan menggunakan model pembelajaran $A R C S$ berbantuan media audio pada kelas eksperimen dan menggunakan model pembelajaran konvensional pada kelas kontrol dengan materi yang sama, yakni menulis surat pribadi.

Tujuan dilakukannya penelitian ini adalah sebagai berikut: (I) untuk menganalisis kemampuan siswa kelas VII SMP Negeri II Medan dalam menulis surat pribadi dengan menggunakan model pembelajaran $A R C S(2)$ untuk menganalisis kemampuan siswa kelas VII SMP Negeri II Medan dalam menulis surat pribadi dengan menggunakan model pembelajaran konvensional, dan (3) untuk menganalisis efektivitas penggunaan model pembelajaran $A R C S$ terhadap kemampuan menulis surat pribadi siswa kelas VII SMP Negeri II Medan. Hasil dari penelitian ini juga dapat digunakan guru sebagai salah satu referensi yang bisa diterapkan baik dalam materi pembelajaran menulis surat pribadi maupun materi pembelajaran bahasa Indonesia lainnya.

\section{METODE}

Penelitian ini dilakukan di SMP Negeri II Medan pada siswa kelas VII tahun pembelajaran 2019/2020. Populasi dalam penelitian ini adalah seluruh siswa kelas VII di SMP Negeri II Medan tahun pembelajaran 2019/2020 dengan jumlah sebanyak 255 siswa. Dalam proses pengambilan sampel digunakan teknik simple random sampling, yakni pengambilan anggota sampel dari populasi dilakukan secara acak tanpa memperhatikan strata yang ada dalam populasi itu, sehingga diperoleh dua kelas sebagai sampel dalam penelitian ini, yakni kelas VII-2 dan kelas VII-4.

Metode penelitian yang digunakan adalah metode eksperimen dengan menggunakan pendekatan kuantitatif. Sebab pada dasarnya penelitian kuantitatif merupakan suatu proses untuk menemukan pengetahuan dengan menggunakan data berupa angka untuk menentukan keterangan tentang sesuatu yang kita cari. Penelitian ini menggunakan dua jenis variabel, yaitu variabel bebas; model pembelajaran $A R C S$ dan yang menjadi variabel terikat adalah menulis surat pribadi.

Desain penelitian yang digunakan adalah post-test only control group design. Dalam desain ini terdapat dua kelas yang masing-masing dipilih secara random dengan dua perlakuan yang berbeda. Kelompok pertama diberi perlakuan disebut sebagai kelas eksperimen, sedangkan kelompok yang tidak diberi perlakuan atau diberikan perlakuan yang berbeda disebut sebagai kelompok kontrol. Maka, dalam penelitian ini kelas VII-4 sebagai kelas eksperimen diberikan model pembelajaran ARCS dan kelas VII2 sebagai kelas kontrol diberikan model pembelajaran konvensional. Untuk menunjang data dalam penelitian ini digunakan dua instrumen penelitian, yaitu observasi dan tes. Observasi dilakukan untuk mengumpulkan data mengenai kemampuan awal siswa menulis surat pribadi, sedangkan tes digunakan untuk mengumpulkan data mengenai kemampuan siswa menulis surat pribadi setelah mendapat perlakuan.

Langkah-langkah penerapan model pembelajaran $A R C S$ dalam kelas eksperimen adalah sebagai berikut: (I) mengingatkan kembali peserta didik pada konsep yang telah dipelajari, (2) menyampaikan tujuan dan manfaat pembelajaran, (3) memberikan kesempatan peserta didik berpartisipasi dalam pembelajaran, (4) memberi umpan balik, (5) menyampaikan materi pembelajaran, (6) mendengarkan media audio yang telah disiapkan oleh peneliti, (7) materi bimbingan belajar, (8) memulai penulisan surat pribadi, (9) menyimpulkan materi yang telah disampaikan di akhir pembelajaran dengan jelas dan terperinci. Langkah- langkah penerapan model pembelajaran konvensional dalam kelas kontrol adalah sebagai berikut: (I) menyampaikan tujuan, (2) menyajikan informasi, (3) mengecek pemahaman dan 
memberikan umpan balik, (4) memberikan kesempatan latihan. Instrumen penilaian menulis surat pribadi sebagaimana pada Tabel I:

Tabel I

Instrumen Penilaian Menulis Surat Pribadi

\begin{tabular}{|c|c|c|c|}
\hline No & Aspek Penilaian & Skor & $\begin{array}{r}\text { Kriteria Penilaian } \\
\end{array}$ \\
\hline \multirow{7}{*}{ I } & Sistematika surat pribadi: & 3 & Semua unsur tercantum \\
\hline & a. alamat dan tanggal surat & 2 & Tercantum $4-5$ unsur \\
\hline & b. alamat yang dituju & I & Tercantum I-3 unsur \\
\hline & c. salam pembuka & 0 & Tidak ada unsur yang tercantum \\
\hline & d. isi surat & & \\
\hline & e. salam penutup & & \\
\hline & f. nama dan tanda tangan & & \\
\hline \multirow{4}{*}{2} & Ciri kebahasaan surat pribadi (menggunakan & 3 & Seluruh unsur dituliskan benar \\
\hline & bahasa yang sopan dan santun, ragam bahasa & 2 & 2 unsur dituliskan dengan benar \\
\hline & sesuai dengan penerima surat, memilki & $\mathrm{I}$ & I unsur dituliskan dengan benar \\
\hline & kesesuaian topik dengan isi surat) & 0 & Tidak ada unsur yang dituliskan dengan benar \\
\hline \multirow{4}{*}{3} & & 3 & Kedua unsur dituliskan dengan tepat \\
\hline & Penggunaan diksi & 2 & Salah satu unsur dituliskan dengan tepat \\
\hline & (ketepatan dan kesesuaian) & I & Kedua unsur dituliskan dengan kurang tepat \\
\hline & & 0 & Tidak ada unsur yang dituliskan dengan tepat \\
\hline \multirow{4}{*}{4} & Ejaan dan tanda baca (penulisan kata, & 3 & Seluruh unsur dituliskan dengan benar \\
\hline & $\begin{array}{l}\text { Ejaan dan tanda Daca (penulisan Kata, } \\
\text { penggunaan huruf kapital dan penggunaan }\end{array}$ & 2 & 2 unsur dituliskan dengan benar \\
\hline & tanda baca) & 1 & I unsur dituliskan dengan benar \\
\hline & & 0 & Tidak ada unsur yang dituliskan dengan benar \\
\hline \multirow{4}{*}{5} & Kerapian dan keindahan surat (tulisan dapat & 3 & Seluruh unsur terpenuhi \\
\hline & dibaca dengan baik (rapi), tidak terdapat & 2 & 2 unsur terpenuhi \\
\hline & & I & I unsur terpenuhi \\
\hline & coretan, surat dihias secara menarık & 0 & Tidak ada unsur yang terpenuhi \\
\hline
\end{tabular}

Untuk mendapatkan nilai dari skor tersebut dilakukan dengan cara sebagai berikut.

$$
\text { Nilai Akhir }=\frac{\text { Skor yang diperoleh }}{\text { Skor maksimal }} \times 100
$$

Analisis data menggunakan teknik analisis data komparasional. Beberapa langkah yang dilakukan untuk memperoleh data adalah: (I) mentabulasi skor dan rata-rata post-test kelas eksperimen dan kelas kontrol, (2) menghitung standar deviasi variabel dari hasil post-test, (3) melakukan uji prasyarat yang meliputi uji normalitas dan homogenitas dengan menggunakan uji liliefors, dan (4) melakukan uji hipotesis dengan menggunakan uji " $\mathrm{t}$ ".

\section{HASIL DAN PEMBAHASAN}

\section{HASIL}

Hasil penelitian ini diuraikan menjadi tiga bagian, yakni: (a) kemampuan siswa menulis surat pribadi dengan menggunakan model pembelajaran $A R C S$, (b) kemampuan siswa menulis surat pribadi dengan menggunakan model pembelajaran konvensional, serta (c) efektivitas model pembelajaran $A R C S$ terhadap kemampuan siswa dalam menulis surat pribadi.

\section{Kemampuan Siswa Menulis Surat Pribadi dengan Menggunakan Model Pembelajaran ARCS}

Berdasarkan nilai hasil belajar dalam menulis surat pribadi dengan menggunakan model pembelajaran ARCS (Attention, Relevance, Confidence, Satisfaction), diperoleh penyebaran nilai sebesar 73 sampai I00. Maka, nilai tertinggi yang diperoleh siswa adalah IOO dan nilai terendah yang diperoleh siswa sebesar 73. Kemudian, setelah dilakukan perhitungan, diperoleh nilai rata-rata kemampuan siswa dalam menulis surat pribadi dengan menggunakan model pembelajaran ARCS (Attention, Relevance, Confidence, Satisfaction) adalah 85,58 dan standar deviasi adalah 7,94 serta standar error sebesar I,4I. Kemampuan tersebut telah melampaui KKM yang ditentukan oleh sekolah, yaitu sebesar 75. Dalam hal 
ini, menulis surat pribadi dengan menggunakan model pembelajaran ARCS berada pada kategori sangat baik jika dikaitkan dengan rentang nilai. Perolehan data dari lapangan dapat dideskripsikan dalam Tabel 2.

Tabel 2

Identifikasi Kecenderungan Hasil Kemampuan Menulis Surat Pribadi dengan Menggunakan Model Pembelajaran ARCS

\begin{tabular}{ccc}
\hline Rentang & F. Absolute & Kategori \\
\hline $85-100$ & 20 & Sangat Baik \\
$70-84$ & II & Baik \\
$60-69$ & 0 & Cukup \\
$50-59$ & 0 & Kurang \\
$0-49$ & 0 & Sangat Kurang \\
& 31 & \\
\hline
\end{tabular}

Berdasarkan Tabel 2, dapat diketahui bahwa kemampuan siswa dalam menulis surat pribadi dengan menggunakan model pembelajaran ARCS (Attention, Relevance, Confidence, Satisfaction) terbagi atas: kategori sangat baik 20 siswa (65\%), kategori baik sebanyak II siswa (35\%), kategori cukup 0 siswa $(0 \%)$, kategori kurang 0 siswa $(0 \%)$ dan kategori sangat kurang $0(0 \%)$.

\section{Kemampuan Siswa Menulis Surat Pribadi dengan Menggunakan Model Pembelajaran Konvensional}

Berdasarkan nilai hasil belajar dalam menulis surat pribadi dengan menggunakan model pembelajaran konvensional, diperoleh penyebaran nilai sebesar 47 sampai dengan 93. Maka, nilai tertinggi yang diperoleh siswa sebesar 93 dan nilai terendah yang diperoleh adalah 47.

Selanjutnya, dilakukan perhitungan analisis data, diperoleh nilai rata-rata kemampuan siswa dalam menulis surat pribadi dengan menggunakan model pembelajaran konvensional adalah 73,56 dan standar deviasi adalah I0,86 serta standar error sebesar I,94. Kemampuan tersebut belum mencapai KKM yang ditentukan oleh sekolah, yaitu sebesar 75. Dalam hal ini, kemampuan siswa menulis surat pribadi dengan menggunakan model pembelajaran konvensional berada pada kategori baik jika dikaitkan dengan rentang nilai. Perolehan data dari lapangan dapat dideskripsikan dalam Tabel 3.

Tabel 3

Identifikasi Kecenderungan Hasil Kemampuan Menulis Surat Pribadi dengan Menggunakan Model Pembelajaran Konvensional

\begin{tabular}{ccc}
\hline Rentang & F. Absolute & Kategori \\
\hline $85-100$ & 6 & Sangat Baik \\
$70-84$ & I3 & Baik \\
$60-69$ & II & Cukup \\
$50-59$ & 0 & Kurang \\
$0-49$ & I & Sangat Kurang \\
& 32 & \\
\hline
\end{tabular}

Berdasarkan Tabel 3, dapat diketahui bahwa kemampuan siswa dalam menulis surat pribadi dengan menggunakan model pembelajaran konvensional terbagi atas: kategori sangat baik 6 siswa (20\%), kategori baik sebanyak I3 siswa (4I\%), kategori cukup II siswa (36\%), kategori kurang 0 siswa (0\%) dan kategori sangat kurang I (3\%).

\section{Efektivitas Model Pembelajaran ARCS terhadap Kemampuan Siswa dalam Menulis Surat Pribadi}

Untuk mengetahui lebih lanjut apakah model pembelajaran $A R C S$ efektif terhadap kemampuan menulis surat pribadi, maka dilakukan uji persyaratan analisis (normalitas dan homogenitas) dan uji hipotesis. 


\section{a. Uji Normalitas}

Untuk menguji normalitas data digunakan uji normalitas liliefors. Pada data kemampuan siswa menulis surat pribadi dengan menggunakan model pembelajaran $A R C S$, diperoleh data Lhitung sebesar 0,1370. Setelah Lhitung diketahui, selanjutnya dikonsultasikan melalui uji liliefors pada taraf signifikasi $\alpha=$ 0,05 dan $\mathrm{n}=3 \mathrm{I}$, diperoleh $\mathrm{L}_{\mathrm{tabel}}=0$,159I. Dengan demikian, dapat disimpulkan bahwa $\mathrm{L}_{\text {hitung }}<\mathrm{L}_{\mathrm{tabel}}$ yaitu $0, \mathrm{I} 370<0, \mathrm{I} 59 \mathrm{I}$. Oleh sebab itu, data kemampuan menulis surat pribadi dengan menggunakan model ARCS (Attention, Relevance, Confidence, Satisfaction) berdistribusi normal.

Selanjutnya, pada data kemampuan siswa menulis surat pribadi dengan menggunakan model pembelajaran konvensional, diperoleh data Lhitung $=0$, I I 44. Setelah Lhitung diketahui, selanjutnya kembali dikonsultasikan melalui uji liliefors pada taraf signifikasi $\alpha=0,05$ dan $n=32$, diperoleh $L_{\text {tabel }}=0,1566$. Dengan demikian dapat disimpulkan bahwa Lhitung $<$ Label yaitu 0,I I 44<0,I566. Oleh karena itu, data kemampuan menulis surat pribadi dengan menggunakan model pembelajaran konvensional berdistribusi normal.

Berikut merupakan data uji normalitas kemampuan siswa menulis surat pribadi dengan menggunakan model ARCS dan konvensional seperti Tabel 4.

Tabel 4

Data Hasil Uji Normalitas

\begin{tabular}{|c|c|c|c|c|}
\hline No & & Lhitung & Ltabel & Keterangan \\
\hline I & $\begin{array}{l}\text { Post-Test } \\
\text { Kelas Eksperimen }\end{array}$ & 0,1370 & $0,159 I$ & Normal \\
\hline 2 & $\begin{array}{l}\text { Post-Test } \\
\text { Kelas Kontrol }\end{array}$ & $0, \mathrm{II} 44$ & 0,1566 & Normal \\
\hline
\end{tabular}

\section{b. Uji Homogenitas}

Untuk melakukan pengujian homogenitas data dilakukan uji homogenitas dua varians, yaitu varians terbesar dan varians terkecil. Maka diperoleh $F_{\text {hitung }}=1,96$ dan dari tabel distribusi $\mathrm{F}$ untuk $\alpha=0,05$ diperoleh $F_{\text {tabel }}=4$,I7. Jadi $F_{\text {hitung }}<F_{\text {tabel }}$ yakni I,96 $<4,17$ serta dapat disimpulkan bahwa sampel penelitian berasal dari populasi yang homogen.

\section{c. Uji Hipotesis}

Setelah pengujian normalitas dan homogenitas dilakukan, maka diketahui bahwa data sebelum dan sesudah perlakuan adalah berdistribusi normal dan mempunyai varians yang sama (homogen). Dengan demikian, pengujian hipotesis dilakukan dengan menggunakan uji statistik t (uji beda).

Berdasarkan perhitungan yang telah dilakukan, diperoleh nilai thitung $=5,0 \mathrm{I}$. Setelah thitung diketahui, selanjutnya nilai tersebut dikonsultasikan pada taraf signifikansi $\alpha=0,05$ diperoleh tabel $=2,040$. Dengan demikian dapat disimpulkan bahwa thitung $>$ trabel yaitu 5,0I $>2,040$, sehingga hipotesis nihil ( $\left.\mathrm{H}_{0}\right)$ ditolak dan hipotesis alternatif $\left(\mathrm{H}_{\mathrm{a}}\right)$ diterima.

\section{PEMBAHASAN}

\section{Kemampuan Siswa Menulis Surat Pribadi dengan Menggunakan Model Pembelajaran ARCS}

Sesuai dengan hasil penelitian yang sudah diperoleh, nilai rata-rata siswa dalam menulis surat pribadi adalah 85,58. Perolehan nilai tersebut berdasarkan aspek-aspek penilaian menulis surat pribadi yang terdapat dalam indikator penilaian dalam penelitian ini. Setiap aspek penilaian menulis surat pribadi memiliki kriteria yang berbeda-beda. Hasil nilai yang diperoleh dalam setiap aspek penilaian juga berbeda. Berikut merupakan penjabaran aspek penilaian menulis surat pribadi siswa dengan menggunakan model pembelajaran ARCS. 


\section{Sistematika Surat Pribadi}

Sistematika surat merupakan salah satu aspek penilaian dalam menulis surat pribadi. Sistematika surat pribadi meliputi: alamat dan tanggal surat, alamat yang dituju, salam pembuka, isi surat, salam penutup, serta nama dan tanda tangan. Skor maksimal dalam aspek penilaian ini adalah 3. Dalam menuliskan sistematika surat pribadi, yang mendapat skor 3 sebanyak 29 siswa, yang mendapat skor 2 sebanyak 2 siswa dan tidak ada yang mendapat skor I maupun 0 dalam aspek penilaian ini. Berdasarkan nilai tersebut, diperoleh nilai rata-rata sebesar 2,93, kemudian dibagi dengan skor maksimal (3) dan dikali seratus (I00). Jadi nilai rata-rata yang diperoleh adalah 97. Dengan demikian, dapat disimpulkan bahwa kemampuan siswa dalam menulis sistematika surat pribadi dengan menggunakan model pembelajaran $A R C S$ termasuk dalam kategori sangat baik.

\section{Ciri Kebahasaan Surat Pribadi}

Salah satu aspek penilaian dalam menulis surat pribadi ini meliputi tiga hal, yakni: menggunakan bahasa yang sopan dan santun, ragam bahasa sesuai dengan penerima surat dan memiliki kesesuaian topik dengan isi surat. Skor maksimal dalam aspek penilaian ini adalah 3. Dalam ketepatan penggunaan ciri kebahasaan surat pribadi, seluruh siswa mendapat nilai 3 dan tidak ada siswa yang mendapat nilai 2, I maupun 0. Berdasarkan nilai tersebut, diperoleh nilai rata-rata sebesar 3, kemudian dibagi dengan skor maksimal (3) dan dikali seratus (I00). Jadi nilai rata-rata yang diperoleh adalah IO0. Dengan demikian, dapat disimpulkan bahwa kemampuan siswa dalam ketepatan penggunaan ciri kebahasaan surat pribadi dengan menggunakan model pembelajaran $A R C S$ termasuk dalam kategori sangat baik.

\section{Penggunaan Diksi}

Dalam aspek penilaian ini, hal-hal yang dinilai adalah ketepatan dan kesesuaian. Skor maksimal dalam aspek penilaian ini adalah 3. Dalam ketepatan penggunaan diksi, yang mendapat skor 3 sebanyak I9 siswa, yang mendapat skor 2 sebanyak 6 siswa, yang mendapat skor I sebanyak 6 siswa dan tidak ada yang mendapat nilai 0 dalam aspek penilaian ini. Berdasarkan nilai tersebut, diperoleh nilai rata-rata sebesar 2,4I, kemudian dibagi dengan skor maksimal (3) dan dikali seratus (IOO). Jadi nilai rata-rata yang diperoleh adalah 80. Dengan demikian, dapat disimpulkan bahwa kemampuan siswa dalam ketepatan penggunaan diksi dengan menggunakan model pembelajaran $A R C S$ termasuk dalam kategori baik.

\section{Ejaan dan Tanda Baca}

Hal-hal yang dinilai dalam aspek penilaian ini adalah penulisan kata, penggunaan huruf kapital dan penggunaan tanda baca. Skor maksimal dalam aspek penilaian ini adalah 3. Dalam penulisan ejaan dan tanda baca, yang mendapat skor 3 sebanyak 4 siswa, yang mendapat skor 2 sebanyak 17 siswa, yang mendapat skor I sebanyak IO siswa dan tidak ada yang mendapat nilai 0 dalam aspek penilaian ini. Berdasarkan nilai tersebut, diperoleh nilai rata-rata sebesar I,80, kemudian dibagi dengan skor maksimal (3) dan dikali seratus (I00). Jadi nilai rata-rata yang diperoleh adalah 60. Dengan demikian, dapat disimpulkan bahwa kemampuan siswa dalam penulisan ejaan dan tanda baca dengan menggunakan model pembelajaran $A R C S$ termasuk dalam kategori cukup.

\section{Kerapian dan Keindahan Surat}

Kerapian dan keindahan surat merupakan aspek terakhir dalam aspek penilaian menulis surat pribadi. Aspek penilaian ini meliputi: tulisan dapat dibaca dengan baik, tidak terdapat coretan dan surat dihias secara menarik. Skor maksimal dalam aspek penilaian ini adalah 3. Dalam aspek keindahan dan kerapian surat, yang mendapat skor 3 sebanyak 2I siswa, yang mendapat skor 2 sebanyak IO siswa dan tidak ada yang mendapat skor I maupun 0 dalam aspek penilaian ini. Berdasarkan nilai tersebut, diperoleh nilai rata-rata sebesar 2,67, kemudian dibagi dengan skor maksimal (3) dan dikali seratus (IO0). Jadi nilai rata-rata yang diperoleh adalah 89. Dengan demikian, dapat disimpulkan bahwa kemampuan siswa dalam 
keindahan dan kerapian surat dengan menggunakan model pembelajaran $A R C S$ termasuk dalam kategori sangat baik.

\section{Kemampuan Siswa Menulis Surat Pribadi dengan Menggunakan Model Pembelajaran Konvensional}

Nilai rata-rata siswa dalam menulis surat pribadi dengan menggunakan model pembelajaran konvensional adalah 73,56. Perolehan nilai tersebut didasarkan pada aspek-aspek penilaian menulis surat pribadi yang terdapat dalam indikator penilaian dalam penelitian ini. Berikut merupakan penjabaran aspek penilaian menulis surat pribadi siswa dengan menggunakan model pembelajaran konvensional.

\section{Sistematika Surat Pribadi}

Dalam menuliskan aspek sistematika surat pribadi, siswa yang mendapat skor 3 sebanyak I9 siswa, yang mendapat skor 2 sebanyak I0 siswa, yang mendapat nilai I sebanyak 3 siswa dan tidak ada siswa yang mendapat nilai 0 dalam aspek penilaian ini. Berdasarkan nilai tersebut, diperoleh nilai rata-rata sebesar 2,50, kemudian dibagi dengan skor maksimal (3) dan dikali seratus (I00). Jadi nilai rata-rata yang diperoleh adalah 83,3. Dengan demikian, dapat disimpulkan bahwa kemampuan siswa dalam menulis sistematika surat pribadi dengan menggunakan model pembelajaran konvensional termasuk dalam kategori baik.

\section{Ciri Kebahasaan Surat Pribadi}

Dalam aspek ketepatan penggunaan ciri kebahasaan surat pribadi, siswa yang mendapat nilai 3 sebanyak I5 siswa, yang mendapat nilai 2 sebanyak I6 siswa dan yang mendapat nilai I sebanyak I siswa serta tidak ada siswa yang mendapat nilai 0 . Berdasarkan nilai tersebut, diperoleh nilai rata-rata sebesar 2,46, kemudian dibagi dengan skor maksimal (3) dan dikali seratus (I00). Jadi nilai rata-rata yang diperoleh adalah 8I. Dengan demikian, dapat disimpulkan bahwa kemampuan siswa dalam Dalam ketepatan penggunaan ciri kebahasaan surat pribadi dengan menggunakan model pembelajaran konvensional termasuk dalam kategori baik.

\section{Penggunaan Diksi}

Dalam ketepatan penggunaan diksi, yang mendapat skor 3 sebanyak II siswa, yang mendapat skor 2 sebanyak I4 siswa, yang mendapat skor I sebanyak 7 siswa dan tidak ada yang mendapat nilai 0 dalam aspek penilaian ini. Berdasarkan nilai tersebut, diperoleh nilai rata-rata sebesar 2,2 I, kemudian dibagi dengan skor maksimal (3) dan dikali seratus (I00). Jadi nilai rata-rata yang diperoleh adalah 7I,86. Dengan demikian, dapat disimpulkan bahwa kemampuan siswa dalam ketepatan penggunaan diksi dengan menggunakan model pembelajaran konvensional termasuk dalam kategori baik.

\section{Ejaan dan Tanda Baca}

Dalam penulisan ejaan dan tanda baca, yang mendapat skor 3 sebanyak 3 siswa, yang mendapat skor 2 sebanyak I0 siswa, yang mendapat skor I sebanyak I6 siswa dan yang mendapat nilai 0 sebanyak 3 siswa. Berdasarkan nilai tersebut, diperoleh nilai rata-rata sebesar I,40, kemudian dibagi dengan skor maksimal (3) dan dikali seratus (I00). Jadi nilai rata-rata yang diperoleh adalah 49,3. Dengan demikian, dapat disimpulkan bahwa kemampuan siswa dalam penulisan ejaan dan tanda baca dengan menggunakan model pembelajaran konvensional termasuk dalam sangat kurang.

\section{Kerapian dan Keindahan Surat}

Dalam aspek keindahan dan kerapian surat, yang mendapat skor 3 sebanyak 16 siswa, yang mendapat skor 2 sebanyak 15 siswa dan tidak ada yang mendapat skor I sebanyak I siswa dan tidak ada siswa yang mendapat nilai 0 dalam aspek penilaian ini. Berdasarkan nilai tersebut, diperoleh nilai rata-rata sebesar 2,43, kemudian dibagi dengan skor maksimal (3) dan dikali seratus (I00). Jadi nilai rata-rata yang 
diperoleh adalah 82. Dengan demikian, dapat disimpulkan bahwa kemampuan siswa dalam keindahan dan kerapian surat dengan menggunakan model pembelajaran konvensional termasuk dalam kategori baik.

\section{Efektivitas Model Pembelajaran $A R C S$ terhadap Kemampuan Siswa dalam Menulis Surat Pribadi}

Merujuk pada hasil penelitian yang telah dijabarkan, perolehan skor siswa menulis surat pribadi dengan menggunakan model $A R C S$ (kelas eksperimen) lebih unggul dibandingkan dengan skor siswa menulis surat pribadi dengan menggunakan model konvensional (kelas kontrol). Hal tersebut dapat dilihat dari hasil nilai ratarata tiap-tiap kelas. Nilai rata-rata kelas eksperimen sebesar 85,58 dengan penyebaran nilai sebesar 73 sampai dengan 100 sedangkan nilai rata-rata kelas kontrol diperoleh sebesar 73,56 dengan penyebaran sebesar 47 sampai dengan 93.

Berkaitan dengan hal tersebut, belum ada laporan terdahulu yang mengaji penerapan model tersebut terhadap kemampuan menulis surat pribadi. Namun demikian, ada beberapa penelitian tentang penerapan model $A R C S$ yang dibandingkan dengan model konvensional. Terdapat perbedaan hasil yang signifikan antara model pembelajaran ARCS dengan model konvensional. Hasil-hasil penelitian tersebut dilaporkan bahwa hasil belajar siswa (Septian dan Farid, 2019; Setyadin dan Joko, 2013), kontribusi motivasi siswa (Afjar, dkk., 2019; Winaya, dkk., 2013) dan kepuasan siswa (Setyadin dan Joko, 2013) dengan menggunakan model ARCS lebih tinggi dibandingkan dengan menggunakan model konvensional.

Dari serangkaian aktivitas belajar yang dilakukan siswa di kelas eksperimen, pembelajaran dengan menggunakan model pembelajaran $A R C S$ mampu membuat siswa termotivasi untuk belajar dan menulis. Hal ini sejalan dengan pernyataan Stefany, Candiasa, \& Warpala, (2016) bahwa model pembelajaran $A R C S$ secara optimal dapat memberikan dampak positif dan memberikan percaya diri lebih terhadap pembelajar (Zhang, 2015) dalam upaya meningkatkan hasil belajar dan motivasi siswa. Terjadinya peningkatan motivasi yang disebabkan oleh penerapan model ARCS ditunjukkan dengan berbagai perubahan tingkah laku dan kemampuan yang dimiliki siswa dari berbagai aspek, di antaranya: dari aspek hasrat dan keinginan untuk berhasil, dorongan dan kebutuhan dalam belajar, cita-cita dan harapan masa depan, penghargaan dalam belajar dan lingkungan belajar yang kondusif (Nugroho dan Wahyuni, 2018). Selain itu, model $A R C S$ juga dapat meningkatkan kemampuan komunikasi siswa (Nabilla Miharjo, dkk, 2019) dan mampu mengatasi hambatan dan kesulitan siswa untuk berkonsentrasi serta dapat memudahkan siswa memahami materi yang sifatnya abstrak (Susanti dan Imbiri, 2020). Dengan demikian, kesulitan-kesulitan menulis yang dialami siswa dapat terbantu dengan adanya penerapan model ini.

Secara lebih rinci, hasil kemampuan siswa menulis surat pribadi dengan menggunakan model pembelajaran ARCS bisa menjadi lebih tinggi dibandingkan dengan model konvensional didasarkan atas beberapa faktor yang mempengaruhi. Faktor-faktor yang mempengaruhi adanya perbedaan yang cukup signifikan antara hasil kelas eksperimen dan kelas kontrol adalah penerapan komponen-komponen model ARCSitu sendiri. Berikut merupakan penjabaran dari tiap-tiap komponen model tersebut.

\section{Attention (Perhatian)}

Aspek attention (perhatian) menuntut siswa untuk lebih berkonsentrasi dalam proses pembelajaran, sehingga siswa lebih memusatkan perhatiannya terhadap materi yang sedang dipelajari (Asfuriyah dan Nuswowati, 2015). Realisasi komponen attention (perhatian) berdasarkan langkah model pembelajaran $A R C S$ dan penerapan media audio. Langkah model pembelajaran $A R C S$ yang termasuk dalam komponen ini adalah menggunakan contoh konkrit. Selain komponen attention (perhatian), langkah ini juga termasuk dalam komponen relevance (relevansi). Sebab pada langkah ini, guru akan memberikan contoh-contoh yang nyata dan memiliki hubungan dengan kehidupan sehari-hari, seperti: pengalaman siswa serta hal- hal lain yang sangat dekat dan berkaitan dengan kehidupan siswa. Maka, aspek penilaian siswa yang memiliki hubungan dengan komponen attention (perhatian) berdasarkan langkah model $A R C S$ adalah sistematika surat pribadi, serta ejaan dan tanda baca. Hal ini dilakukan guru dengan cara memberitahukan setiap fungsi sistematika surat pribadi serta ejaan dan tanda baca secara satu per satu dengan menyertakan contoh konkrit dari setiap

Ervira Dwi Lesmana, Fitriani Lubis, Efektivitas model pembelajaran ARCS terhadap kemampuan menulis surat pribadi siswa kelas VII SMPN 11 Medan 
fungsi sistematika surat tersebut dan menyatakan beberapa kemungkinan terjadinya kesalahan dalam menuliskan hal-hal tersebut. Sebab, salah satu strategi untuk mengaplikasikan aspek perhatian adalah menghadirkan sebuah kejanggalan/konflik serta menyajikan contoh-contoh (Keller, 2017). Selain itu, guru juga turut membandingkan sistematika surat pribadi dengan surat dinas yang telah dipelajari sebelumnya oleh siswa. Hal tersebut membuat siswa lebih memahami materi sistematika surat pribadi dan lebih termotivasi untuk mendengarkan penjelasan dari guru.

Selanjutnya, strategi lain dari aspek attention (perhatian) adalah menggunakan teknologi atau sesuatu yang lain guna menstimulasi siswa untuk turut berpartisipasi dalam pembelajaran (Keller, 2017). Aspek penilaian siswa yang memiliki hubungan dengan komponen attention (perhatian) berdasarkan penerapan media audio adalah ciri kebahasaan surat pribadi. Media pembelajaran audio merupakan media pembelajaran yang terbilang cukup baru bagi siswa karena sebelumnya guru belum pernah menggunakan media ini dalam menerapkan pembelajaran di kelas. Karena merasa penasaran dan gembira, siswa secara tidak langsung memusatkan perhatiannya kepada audio tersebut, sehingga instruksi yang diberikan guru sebelum proses pemutaran audio pun dipatuhi dengan baik oleh siswa. Tentu hal ini sangat baik karena siswa antusias untuk mengikuti proses pembelajaran dan mendengarkan media audio yang telah disiapkan dengan seksama.

\section{Relevance (Relevansi)}

Sama halnya dengan komponen attention (perhatian), komponen relevance (relevansi) dapat terealisasi berdasarkan langkah model pembelajaran $A R C S$ dan penerapan media audio. Andari dan Lusiana (2016), menyatakan bahwa siswa akan terdorong untuk mempelajari sesuatu jika sesuatu tersebut memiliki tujuan yang jelas dan ada relevansinya dengan kehidupan mereka. Langkah-langkah model pembelajaran $A R C S$ yang termasuk dalam komponen ini adalah (I) menyampaikan tujuan dan manfaat pembelajaran, (2) menyampaikan materi pembelajaran, dan (3) menggunakan contoh konkrit. Maka, aspek penilaian siswa yang memiliki hubungan dengan komponen relevance (relevansi) berdasarkan langkah model ARCS adalah seluruh aspek penilaian surat pribadi. Sebab, guru menyampaikan tujuan dan manfaat mempelajari surat pribadi dan seluruh aspek surat pribadi disampaikan guru dengan menggunakan contoh-contoh yang konkret.

Selanjutnya, aspek penilaian siswa yang memiliki hubungan dengan komponen relevance (relevansi) berdasarkan penerapan media audio adalah ciri kebahasaan surat pribadi dan penggunaan diksi. Media pembelajaran audio yang digunakan berisi tentang perjuangan orang tua. Mulai dari perjuangan seorang ibu melahirkan anaknya dan seorang ayah yang berjuang mencari nafkah untuk keluarganya, kemudian perjuangan keduanya merawat dan mendidik anak-anaknya. Hal tersebut relevan dengan topik penulisan surat pribadi yang ditentukan, yakni tentang perjuangan orang tua. Selain itu, karena penerima surat adalah orang tua, maka siswa juga dapat menuliskan bahasa yang sesuai dengan penerima surat yang dalam hal ini juga relevan dengan media audio yang telah disajikan. Dengan mendengarkan media audio, siswa mendapatkan inspirasi untuk menuangkan gagasannya. Siswa akan lebih mudah memikirkan hal-hal yang akan mereka tulis melalui media yang mereka dengar dan lebih mudah untuk menyesuaikan pilihan kata yang akan mereka gunakan.

\section{Confidence (Percaya Diri)}

Aspek confidence (percaya diri) berfokus pada pembentukan ekspektasi positif untuk mencapai keberhasilan siswa (Malik, 20I4). Komponen confidence (percaya diri) dapat terealisasi berdasarkan langkah model pembelajaran $A R C S$. Langkah-langkah model pembelajaran $A R C S$ yang termasuk dalam komponen ini adalah (I) memberi kesempatan kepada peserta didik untuk berpartisipasi dalam pembelajaran (langkah ini juga termasuk dalam komponen satisfaction), dan (2) materi bimbingan belajar. Maka, aspek penilaian menulis surat pribadi siswa yang memiliki hubungan dengan komponen confidence (percaya diri) berdasarkan langkah model $A R C S$ adalah penggunaan diksi serta kerapian dan keindahan surat. Materi bimbingan belajar adalah salah satu langkah penerapan model pembelajaran $A R C S$. Pada langkah ini, guru memotivasi dan mengarahkan siswa agar lebih mudah memahami materi. Guru menyajikan informasi tentang menulis kepada siswa. 
Guru menjelaskan bahwa menulis memiliki banyak manfaat dan kemudian memotivasi siswa untuk menyukai kegiatan menulis. Kemudian, guru juga membebaskan siswa untuk menghias surat pribadi milik mereka sesuai dengan apa yang mereka inginkan. Salah satu strategi yang tepat dalam menerapkan aspek confidence (percaya diri) adalah self-confidence. Self-confidence dapat dilakukan dengan cara memberikan peluang kepada seluruh siswa untuk meningkatkan kemandirian dalam mempelajari dan mempraktikkan kemampuannya (Keller, 2017). Karena hal tersebut, siswa cukup antusias untuk menulis sehingga berpengaruh pada pilihan kata yang mereka gunakan, serta memiliki kepercayaan diri untuk menuangkan idenya ke dalam bentuk tulisan dan menghias surat pribadi milik mereka dengan indah dan serapi mungkin.

\section{Satisfaction (Kepuasan)}

Komponen terakhir dalam model $A R C S$ ini dapat terealisasi berdasarkan langkah model pembelajaran $A R C S$. Langkah tersebut adalah memberi kesempatan peserta didik untuk berpartisipasi dalam pembelajaran. Maka, aspek penilaian menulis surat pribadi siswa yang berhubungan dengan komponen satisfaction (kepuasan) adalah keindahan dan kerapian surat. Realisasi komponen satisfaction (kepuasan) adalah dengan mengaplikasikan strategi komponen ini. Menurut (Keller, 2017), salah strategi penerapan komponen satisfaction (kepuasan) adalah positive outcomes yang dapat dilakukan memberikan motivasi yang sejalan dengan tugas yang diberikan dan memberikan pujian secara verbal untuk keberhasilan pembelajaran. Siswa diminta menghias surat pribadi milik mereka masing-masing. Rata-rata siswa memiliki antusias yang tinggi jika diminta untuk menghias sesuatu, begitupun dengan menghias surat pribadi milik mereka Ditambah lagi dengan pujian dan motivasi yang diberikan oleh guru untuk berlomba-lomba mempercantik surat pribadi milik mereka dan berhati-hati untuk tidak mengotori surat pribadi milik mereka, siswa semakin bersemangat untuk menghias. Setelah surat pribadi milik siswa selesai dihias, siswa akan merasa puas dengan apa yang sudah mereka kerjakan.

Faktor-faktor yang menyebabkan model pembelajaran konvensional memiliki hasil menulis surat pribadi siswa yang lebih rendah jika dibandingkan dengan model pembelajaran $A R C S$ adalah langkahlangkah model pembelajaran itu sendiri. Langkah-langkah guru dalam menerapkan model pembelajaran konvensional jika dibandingkan dengan langkah model pembelajaran $A R C S$ adalah sebagai berikut:

\section{Menyampaikan tujuan}

Dalam langkah ini, guru menyampaikan tujuan pembelajaran yang ingin dicapai dalam pembelajaran tersebut. Tujuan pembelajaran menulis surat pribadi yang disampaikan guru antara lain adalah sebagai berikut: (I) siswa dapat merencanakan penulisan surat pribadi, (2) siswa dapat memahami penyesuaian konteks dengan penulisan surat pribadi, (3) siswa dapat menulis surat pribadi dengan memperhatikan struktur teks, kebahasaan dan isi. Dalam hal ini, siswa tidak merasa begitu tertarik atau termotivasi mempelajari surat pribadi sebab siswa tidak mengetahui manfaat mempelajari surat pribadi.

Berbeda halnya dengan langkah model pembelajaran $A R C S$ yang tidak hanya menyampaikan tujuan pembelajaran, namun juga menyampaikan manfaat dari mempelajari materi surat pribadi. Tujuan pembelajaran merupakan sesuatu yang ingin dicapai dari pembelajaran tersebut, sedangkan manfaat pembelajaran merupakan dampak dari pencapaian tujuan pembelajaran itu sendiri. Peserta didik akan lebih memahami alasan materi tersebut dipelajari jika tujuan dan manfaat pembelajaran disampaikan secara bersamaan. Sebab, peserta didik akan merasa lebih tertarik jika mereka mengetahui apa manfaat dari mempelajari materi tersebut untuk dirinya sendiri.

Selain itu, pada model pembelajaran konvensional, menyampaikan tujuan menjadi langkah pertama yang dilakukan, sedangkan pada model pembelajaran $A R C S$, langkah pertama yang dilakukan adalah mengingatkan kembali peserta didik pada konsep yang telah dipelajari. Pada langkah ini, guru menarik perhatian peserta didik dengan cara mengulang kembali pelajaran atau materi yang telah dipelajari peserta didik dan mengaitkan materi tersebut dengan materi pelajaran yang akan disajikan (Sulistiani, 2013). Dengan cara ini, peserta didik akan merasa tertarik serta termotivasi untuk memperoleh

Ervira Dwi Lesmana, Fitriani Lubis, Efektivitas model pembelajaran ARCS terhadap kemampuan menulis surat pribadi siswa kelas VII SMPN 11 Medan 
pengetahuan yang baru yaitu materi pembelajaran yang akan disajikan. Hal ini sangat penting untuk dilakukan guna membuat peserta didik lebih siap dan termotivasi untuk mengikuti pembelajaran. Kondisi tersebut membuat siswa kelas eksperimen (menggunakan model ARCS) lebih siap menerima dan memahami materi pembelajaran.

\section{Menyajikan informasi}

Guru menyajikan informasi kepada siswa siswa secara tahap demi tahap dengan metode ceramah. Guru menyajikan informasi seputar sistematika surat pribadi, topik penulisan surat pribadi dan bagaimana cara menulis surat pribadi tanpa mengaitkan hal-hal yang relevan dengan siswa. Sehingga pembelajaran terkesan monoton dan kurang menarik.

Berkaitan dengan langkah menyajikan informasi, model pembelajaran ARCS juga memiliki langkah yang berkesinambungan dengan langkah tersebut, yakni menyampaikan materi pembelajaran. Pada langkah ini, guru menyampaikan materi pembelajaran secara jelas dan terperinci. Penyampaian materi ini dilakukan dengan cara atau strategi yang dapat memotivasi siswa yaitu dengan cara menyajikan pembelajaran tersebut dengan menarik, sehingga dapat menumbuhkan atau menjaga perhatian siswa; memberikan keterkaitan antara materi pembelajaran yang disajikan dengan pengalaman belajar siswa ataupun berhubungan dengan kehidupan sehari-hari siswa; menumbuhkan rasa percaya diri siswa dengan cara memberikan kesempatan kepada siswa untuk bertanya, memberikan tanggapan, menciptakan rasa puas di dalam diri siswa dengan cara memberikan penghargaan atas kinerja atau hasil kerja siswa (Sulistiani, 2013).

Dalam menyampaikan materi, guru juga menerapkan langkah model $A R C S$ selanjutnya, yakni menggunakan contoh konkret. Pada langkah ini, guru memberikan contoh-contoh yang nyata serta ada hubungannya dengan kehidupan sehari-hari peserta didik sehingga peserta didik merasa tertarik untuk mengikuti pembelajaran. Adapun manfaat yang didapatkan dari penggunaan contoh yang konkrit ini adalah untuk menumbuhkan atau menjaga perhatian peserta didik (attention) dan memberikan kesesuaian antara pembelajaran yang disajikan dengan pengalaman belajar peserta didik ataupun kehidupan seharihari peserta didik (relevance). Tidak hanya sekadar menyampaikan materi dengan menggunakan contoh konkrit, model pembelajaran $A R C S$ juga menerapkan langkah materi bimbingan belajar. Pada langkah ini, guru memotivasi dan mengarahkan peserta didik agar lebih mudah dalam memahami materi pembelajaran yang disajikan. Secara langsung, langkah ini dapat meningkatkan rasa percaya diri peserta didik sehingga peserta didik tidak merasa ragu dalam memberikan respon kepada guru. Pemberian bimbingan belajar ini juga bermanfaat bagi peserta didik yang lambat dalam memahami suatu materi pembelajaran, sehingga peserta didik tersebut merasa termotivasi untuk memahami materi pembelajaran yang disajikan. Dengan demikian, siswa akan lebih merasa termotivasi dan tertarik serta merasa bahwa pembelajaran yang disajikan menyenangkan dan lebih mudah memahami setiap materi yang dijabarkan oleh guru, dibandingkan dengan model pembelajaran konvensional yang terkesan monoton dan membosankan.

\section{Mengecek pemahaman dan memberikan umpan balik}

Mengecek pemahaman dilakukan guru dengan cara mempersilakan siswa untuk bertanya dan kembali bertanya kepada siswa, baik tentang surat yang telah mereka amati tentang materi pembelajaran yang telah disampaikan oleh guru, ataupun seputar topik penulisan surat pribadi yang telah disampaikan.

Langkah dalam model pembelajaran ARCS yang berkesinambungan dengan langkah ini adalah memberikan kesempatan kepada peserta didik untuk berpartisipasi dalam pembelajaran dan memberikan umpan balik. Langkah memberikan kesempatan kepada peserta didik untuk berpartisipasi dalam pembelajaran dilakukan dengan cara memberikan kesempatan kepada peserta didik untuk bertanya, menanggapi, ataupun mengerjakan soal-soal mengenai materi pembelajaran yang disajikan. Dengan memberikan kesempatan kepada peserta didik untuk berpartisipasi ini, peserta didik akan berkompetensi secara sehat dan aktif dalam mengikuti pembelajaran. Memberikan kesempatan kepada peserta didik 
untuk berpartisipasi dalam pembelajaran ini juga dapat menumbuhkan ataupun meningkatkan rasa percaya diri peserta didik dan akhirnya juga dapat menimbulkan rasa puas di dalam diri peserta didik karena merasa ikut terlibat dalam proses pembelajaran tersebut.

Pada langkah memberi umpan balik, guru memberikan satu umpan balik yang tentunya dapat merangsang pola berpikir peserta didik. Setelah pemberian umpan balik ini, peserta didik secara aktif menanggapi feedback dari guru tersebut. Pemberian feedback ini dapat menumbuhkan rasa percaya diri peserta didik dan menimbulkan rasa puas dalam diri peserta didik. Secara umum, langkah mengecek pemahaman dan memberikan umpan balik dalam model konvensional dengan langkah memberikan kesempatan kepada peserta didik untuk berpartisipasi dalam pembelajaran dan memberikan umpan balik dalam model pembelajaran $A R C S$ memiliki fungsi yang sama. Namun, keduanya diaplikasikan secara berbeda. Singkatnya, pada model pembelajaran konvensional, guru mengecek pemahaman siswa dengan cara bertanya kepada siswa kemudian memberikan apresiasi secara verbal.

Pada model pembelajaran $A R C S$, guru akan mendorong siswa untuk menyampaikan pendapat mereka, bertanya ataupun menanggapi apa yang disajikan guru ataupun hal-hal yang terkait dengan pembelajaran baik yang terdapat dalam buku teks maupun hal-hal yang berkaitan dengan kehidupan siswa sehari-hari. Setelah itu, guru akan mengapresiasi dengan berbagai ungkapan motivasi dan meminta siswa yang lainnya untuk bertepuk tangan, sehingga siswa yang berani berpartisipasi secara aktif merasa percaya diri dan tidak merasa takut untuk mengungkapkan gagasannya.

\section{Memberikan kesempatan latihan lanjutan}

Latihan lanjutan yang diberikan dalam langkah ini adalah menulis surat pribadi (post-test). Guru membagikan lembar kerja yang telah disiapkan kepada setiap siswa. Guru juga membagikan beberapa alat yang dapat digunakan (disiapkan oleh peneliti) untuk menghias surat pribadi milik siswa. Kemudian, guru meminta siswa untuk menuliskan gagasan atau perasaan mereka ke dalam surat yang mereka tulis sesuai dengan topik yang telah dijelaskan. Guru mengimbau untuk berhati-hati dalam menulis surat milik mereka, tidak diperbolehkan kotor dan diusahakan untuk tidak ada coretan. Setelah itu, guru juga meminta siswa untuk menghias surat pribadi milik mereka masing-masing sesuai dengan keinginan mereka.

Dalam hal ini, model pembelajaran $A R C S$ juga melakukan langkah yang sama, yakni membagikan lembar kerja kepada peserta didik untuk menulis surat pribadi milik mereka dengan menjelaskan hal-hal teknis terkait penulisan surat yang akan ditulis oleh peserta didik.

\section{Tidak adanya penggunaan media}

Dalam penerapan model pembelajaran konvensional tidak digunakan media untuk membantu keberlangsungan pembelajaran. Media pembelajaran yang digunakan dalam model pembelajaran $A R C S$ sangat menarik perhatian dan minat belajar siswa. Media tersebut sangat relevan dengan pembelajaran, membantu siswa untuk mengungkapkan gagasan atau ide-ide mereka ke dalam bentuk tulisan dengan lebih mudah. Hal-hal baru dalam pembelajaran harus diaplikasikan sebab siswa akan menjadi lebih termotivasi dan bersemangat dalam belajar. Maka, hasil menulis surat pribadi siswa dengan menggunakan model $A R C S$ jauh lebih baik jika dibandingkan dengan menggunakan model pembelajaran konvensional.

Berdasarkan faktor-faktor tersebut, motivasi menjadi landasan utama adanya model pembelajaran $A R C S$. Sebab motivasi merupakan sebuah komponen yang sangat diperlukan untuk menunjang proses pembelajaran. Setelah adanya penerapan strategi-strategi model $A R C S$ yang diungkapkan oleh Keller (20I7) dalam penelitian ini, hasil yang diperoleh sesuai dengan apa yang diharapkan, yakni kemampuan siswa dalam menulis surat pribadi termasuk dalam kategori sangat baik serta memiliki perbedaan hasil yang cukup signifikan dengan kemampuan siswa dalam menulis surat pribadi dengan menggunakan model konvensional. Selanjutnya, Li dan Keller (2018) telah mempertimbangkan bahwa motivasi dari beberapa sub-skala model pembelajaran ARCS memang mempengaruhi motivasi dan prestasi siswa. Selain itu, hal yang sama juga dikemukakan oleh Molaee and Dortaj (2015) bahwa model ARCS telah dianggap sebagai

Ervira Dwi Lesmana, Fitriani Lubis, Efektivitas model pembelajaran ARCS terhadap kemampuan menulis surat pribadi siswa kelas VII SMPN 11 Medan 
kriteria yang berguna untuk membantu meningkatkan motivasi siswa. Terjadinya peningkatan motivasi yang disebabkan oleh penerapan model $A R C S$ ditunjukkan dengan berbagai perubahan tingkah laku dan kemampuan yang dimiliki siswa dari berbagai aspek, diantaranya: dari aspek hasrat dan keinginan untuk berhasil, dorongan dan kebutuhan dalam belajar, cita-cita dan harapan masa depan, penghargaan dalam belajar dan lingkungan belajar yang kondusif (Nugroho dan Wahyuni, 2018).

Mengacu pada beberapa penelitian sebelumnya, beberapa penerapan model ARCS dapat diterapkan dalam pembelajaran bahasa Indonesia dan dilaporkan mampu meningkatkan hasil pembelajaran. Penerapan model $A R C S$ ini dapat diterapkan dalam pembelajaran fabel (Khori, 2018) dan pembelajaran cerita rakyat (Rahayu, 20I5). Beberapa penelitian sebelumnya juga dilaporkan mampu meningkatkan kemampuan siswa menulis surat pribadi dengan menggunakan model dan metode yang bervariasi. Beberapa model dan metode pembelajaran ini merupakan model pembelajaran Make a Match Mind Map dan media gambar (Fajriyah dan Wagiran, 2018), model pembelajaran Examples non Examples (Suyatna, 2017) dan metode kolaborasi (Sriyanti, 2017). Selain penerapan model-model pembelajaran tersebut, guru juga diharapkan dapat membuat penilaian yang disesuaikan buku guru dan teori-teori lain yang relevan guna menciptakan penilaian yang lebih baik.

Jadi, dari penjelasan di atas dan didukung oleh hasil penelitian-penelitian terdahulu dan memiliki relevansi dengan penelitian ini, dapat disimpulkan bahwa kemampuan siswa dalam menulis surat pribadi berpengaruh baik dalam pembelajaran bahasa Indonesia khususnya dengan menggunakan model pembelajaran ARCS (Attention, Relevance, Confidence, Satisfaction). Hal ini memudahkan mereka dalam memotivasi siswa untuk mengikuti proses pembelajaran, memudahkan siswa untuk menuangkan gagasan ke dalam bentuk tulisan dan menyesuaikan topik dengan isi surat yang ditulis. Model pembelajaran $A R C S$ efektif diterapkan untuk meningkatkan kemampuan siswa dalam menulis surat pribadi.

\section{SIMPULAN}

Pada penelitian ini, efektivitas model pembelajaran ARCS (Attention, Relevance, Confidence, Satisfaction) diuji terhadap kemampuan menulis surat pribadi siswa kelas VII tahun pembelajaran 2019/2020. Hasil penelitian menunjukkan bahwa kemampuan siswa menulis surat pribadi dengan menggunakan model pembelajaran $A R C S$ lebih tinggi dibandingkan dengan kemampuan siswa menulis surat pribadi dengan menggunakan model pembelajaran konvensional. Serangkaian aktivitas siswa yang dilakukan dalam model pembelajaran $A R C S$ dapat meningkatkan motivasi menulis dan motivasi belajar siswa.

Berdasarkan hasil yang diperoleh dari studi ini, penerapan model pembelajaran ARCS di sekolahsekolah yang terdapat di Indonesia sangat direkomendasikan. Penyebarluasan informasi yang berkaitan dengan manfaat model pembelajaran $A R C S$ perlu dilakukan agar dapat menjadi salah satu referensi model pembelajaran yang dapat digunakan guru untuk menciptakan variasi dalam pembelajaran dan meningkatkan kemampuan serta hasil belajar siswa. Selain itu, perlu dilakukan penelitian lebih lanjut mengenai model pembelajaran $A R C S$ ini untuk mengetahui kelebihan dan kekurangannya saat diterapkan dalam materi atau pembelajaran yang berbeda serta dapat mengetahui manfaat-manfaat yang diperoleh saat menerapkan model pembelajaran ini.

\section{UCAPAN TERIMA KASIH}

Penulis mengucapkan terima kasih kepada Lembaga Penelitian dan Pengabdian Kepada Masyarakat (LPPM) Universitas Negeri Medan yang telah memberikan dukungan finansial dalam penelitian ini. Penulis juga mengucapkan terima kasih kepada semua pihak yang telah berkontribusi dalam penelitian ini, sehingga penelitian ini dapat terlaksana dengan baik.

\section{DAFTAR PUSTAKA}

Afjar, A. M., Musri, \& Syukri, M. (2019). Attention, relevance, confidence, satisfaction (ARCS) model 
on students' motivation and learning outcomes in learning physics. Journal of Physics: Conference Series, I460 (I). doi: https://doi.org/I0.I088/I742-6596/I460/I/012II9

Andari, T., \& Lusiana, R. (2016). Pengembangan perangkat pembelajaran dengan menggunakan pendekatan quantum learning berbasis needs assesment pada materi ruang-n euclides. JIPM (Jurnal Ilmiah Pendidikan Matematika), 3(I), 66-72. doi: https://doi.org/I0.25273/jipm.v3iI.488

Annamalai, S. (2016). Implementing ARCS model to design a motivating multimedia E-book for polytechnic ESL classroom. Journal of Telecommunication, Electronic and Computer Engineering, 8(8), 57-60.

Aryawan, I., Lasmawan, M., \& Yudana, M. (20I4). Pengaruh penerapan model pembelajaran attention, relevance, confidence, satisfaction (ARCS) dan motivasi berprestasi terhadap hasil belajar IPS pada siswa kelas V Sekolah Dasar Negeri di Gugus XIII Kecamatan Buleleng. Jurnal Pendidikan Dasar Ganesha, 4(I), I22934.

Asfuriyah, S., \& Nuswowati, M. (20I5). Pengembangan majalah sains berbasis contextual learning pada tema pemanasan global untuk meningkatkan minat belajar siswa. USEJ - Unnes Science Education Journal, 4(I), 739-746. doi: https://doi.org/IO.I5294/usej.v4iI.4983

Atmazaki. (2013). Implementasi kurikulum 2013 mata pelajaran bahasa Indonesia: Pola pikir, pendekatan ilmiah, teks (gendre), dan penilaian otentik. Proceeding of the International Seminar on Language and Arts, 2, I5-22.

Dalman. (2013). Keterampilan menulis. Yogyakarta: PT Raja Grafindo Persada.

Dewi, Q. (20I4). Teknik lengkap surat menyurat. Yogyakarta: Arti Bumi Persada.

Fajriyah, N., \& Wagiran. (2018). Keefektifan pembelajaran menulis surat pribadi untuk kepentingan resmi menggunakan model pembelajaran M4 (Make A Match-Mind Map) dengan media gambar pada siswa kelas VII SMP. INSANIA: Jurnal Pemikiran Alternatif Kependidikan, 23(I), 4I-50. doi: https://doi.org/I0.24090/insania.v23iI.2005

Hamdu, G., \& Agustina, L. (20II). Pengaruh motivasi belajar siswa terhadap prestasi belajar IPA di sekolah dasar. Jumal Penelitian Pendidikan, I2(3), 90-96. doi: https://doi.org/I0.3I004/edukatif.vIi3.63

Keller, J. M. (2010). Motivational design for learning performance: The ARCS model approach. London: Springer Science.

Keller, J. M. (2017). Development and use of the ARCS model of motivational design: Classic writings on instructional technology. Journal of Instructional Development, I932, 225-245.

Khori, A. A. (2018). Penerapan model pembelajaran ARCS (Attention, Relevance, Confidence, Satisfaction) terhadap pembelajaran fabel di SMP/MTs kelas VII. Media Didaktika, 4(2), I43I52.

Li, K., \& Keller, J. M. (2018). Use of the ARCS model in education: A literature review. Computers and Education, I22 (March), 54-62. doi: https://doi.org/I0.I016/j.compedu.2018.03.019

Malik, S. (20I4). Effectiveness of arcs model of motivational design to overcome non completion rate of students in distance education. Turkish Online Journal of Distance Education, I5(2), 194-200. doi: https://doi.org/I0.17718/tojde.I8099

Stefany, E. M., Candiasa, I. \& Warpala, I. W. S. (2016). Pengaruh Strategi ARCS (Attention, Relevance, Confidence and Satisfaction) Terhadap Motivasi dan Hasil Belajar TIK Siswa Kelas VIII di SMP Negeri 4 Negara. Jurnal Teknologi Pembelajaran Indonesia, 6(I).I-8.

Molaee, Z., \& Dortaj, F. (2015). Improving L2 learning: An ARCS instructional-motivational approach. Procedia-Social and Behavioral Sciences, I7I, I2I4-I222. doi: https://doi.org/I0.I0I6/j.sbspro.2015.01.234

Munawarah, J., Kasim, U., \& Daud, B. (2018). Improving speaking sub-skills by using the attention, Relevance, Confidence, and Satisfaction (ARCS) model. English Education Journal (EEJ), 9(3), $356-376$. 
Nabilla Miharjo, A., Suryani Lukman, H., \& Mulyanti, Y. (2019). Penerapan model pembelajaran Attention, Relevance, Confidence, Satisfaction (ARCS) terhadap kemampuan komunikasi matematis siswa. Symmetry: Pasundan Journal of Research in Mathematics Learning and Education, 4, 72-80. doi: https://doi.org/I0.23969/symmetry.v4iI.I7I4

Nirbita, B. N. (2017). Penerapan model pembelajaran ARCS (Attention, Relevance, Confidence and Satisfaction) untuk meningkatkan keaktifan, motivasi dan hasil belajar. Jurnal FKIP UNS, 3(2). Retrieved from: http://jurnal.fkip.uns.ac.id/index.php/snpe/article/view/I068I/8358

Nugroho, J. A., \& Wahyuni, S. (2018). Efektivitas penerapan model Attention, Relevance, Confidence, Satisfaction (ARCS) berbantuan video tutorial untuk meningkatkan keaktifan dan motivasi belajar peserta didik di SMK Negeri I Sukoharjo. BISE: Jurnal Pendidikan Bisnis dan Ekonomi, 4(2), I67-I79. Doi: https:/ / doi.org/I0.2096I/bise.v4i2.24534

Popovich, N. G. (2000). Applying the ARCS model of motivational design to pharmaceutical education. American Journal of Pharmaceutical Education, 64(2), I88-196.

Rahayu, D. D. (2015). Strategi pengelolaan motivasional ARCS (Attention, Relevance, Confidence, Satisfaction) dalam menyimak cerita rakyat. Riksa Bahasa: Jurnal Bahasa, Sastra, dan Pembelajarannya, $I(2)$,

II7-I94. doi: https://doi.org/I0.I7509/rb.vIi2.8760

Saddhono, K., \& Slamet. (20I4). Pembelajaran Keterampilan berbahasa Indonesia. Yogyakarta: Graha Ilmu.

Santiani, S. (2013). Analisa Minat Dan Motivasi Belajar Mahasiswa Dengan Angket Respon Model Arcs. Edu Sains: Jurnal Pendidikan Sains dan Matematika, I(I), I7-32. doi: https://doi.org/I0.2397I/eds.viil.25

Septian, D., \& Farid, I. F. (2019). Pembelajaran ipa mengunakan model ARCS (Attention, Relevance, Confidance, and Satisfaction) dengan metode the power of two pada siswa kelas IV SDIT Al Akhyar Bae Kudus. Jurnal Pendidikan Fisika dan Sains (JPFS), 2(2), 56-64. Retrieved from http://journal.unucirebon.ac.id/index.php/jpfs/article/view/70

Setyadin, E., \& Joko. (2013). Perbedaan hasil belajar model pembelajaran Attention, Relevance, Confidence, Satisfaction (ARCS) dengan model pembelajaran konvensional pada kelas X Titl di SMKN 2 Surabaya. Jurnal Pendidikan Teknik Elektro, 2(I), 73-80.

Siregar, E., \& Nara. (2016). Teori Belajar dan Pembelajaran. Yogyakarta: Ghalia Indonesia.

Sriyanti. (2017). Peningkatan kemampuan menulis surat pribadi dengan menggunakan metode kolaborasi (Penelitian Tindakan Kelas VII MTsN 15 Ciamis) Program Studi Pendidikan Bahasa dan Sastra Indonesia. Jurnal Diksatrasia, I(2), I56-I63. Retrieved form: https://jurnal.unigal.ac.id/index.php/diksatrasia/article/view/594/492

Sulistiani. (2013). Efektivitas pembelajaran ARCS (Attention, Relevance, Confidence, Satisfaction) berbantuan alat peraga terhadap peningkatan hasil belajar matematika peserta didik pada pokok bahasan segiempat. Jurnal Matematika Institut Agama Islam Semarang, I(2). 34-43.

Susanti, L., \& Imbiri, C. (2020). Implementasi motivasi model ARCS (Attention, Relevance, Confidence, and Satisfaction) dalam pembelajaran Pendidikan Agama Kristen. DUNAMIS: Jurnal Teologi dan Pendidikan Kristiani, 4(2), 254-263. doi: https://doi.org/I0.30648/dun.v4i2.284

Suyatna. (2017). Peningkatan keterampilan menulis surat pribadi dengan menggunakan model examples non examples pada siswa kelas VIIb SMP IT Nurul Yaqin Kabupaten Sorong. Jurnal Pendidikan, 5(I), 82-90. Retrieved from: https://unimuda.ejournal.id/jurnalpendidikan/article/view/II9/I02

Umar. (20I4). Media pendidikan: Peran dan fungsinya dalam pembelajaran. Jurnal Tarbiyah, II(I), I3I-I44. doi: https://doi.org/I0.28944/afkar.v5iI.I09

Uno, H. (20I I). Teori motivasi dan pengukuran analisis di bidang pendidikan. Yogyakarta: Bumi Aksara.

Wah, L. K. (2015). The effects of instruction using the arcs model and geogebra on upper secondary students' motivation and achievement in learning combined transformation. Asia Pacific Journal 
of Educators and Education, 30, I4I-I58.

Wena, M. (20I I). Strategi pembelajaran inovatif kontemporer. Jakarta: PT Bumi Aksara.

Winaya, A., Made, I., Lasmawan, I. W., \& Dantes, N. (2013). Pengaruh model ARCS terhadap hasil belajar ditinjau Dari motivasi belajar siswa pada pembelajaran ips di Kelas iv sd chis denpasar (Doctoral dissertation, Ganesha University of Education).

Zhang, J. (2015). Improving english listening proficiency: The application of ARCS learningmotivational model. English Language Teaching, 8(10), I-6. doi: https://doi.org/I0.5539/elt.v8nIOpI

Zhang, W. (2017). Design a civil engineering micro-lecture platform based on the ARCS model perspective. International Journal of Emerging Technologies in Learning, I2(I), I07-I I8. doi: https://doi.org/I0.399I/ijet.vI2i01.6487 